\title{
Relatief onaantastbaar
}

Citation for published version (APA):

Verheij, N. (2005). Relatief onaantastbaar. Universiteit Maastricht. https://doi.org/10.26481/spe.20050121nv

Document status and date:

Published: 21/01/2005

DOI:

$10.26481 /$ spe.20050121nv

Document Version:

Publisher's PDF, also known as Version of record

\section{Please check the document version of this publication:}

- A submitted manuscript is the version of the article upon submission and before peer-review. There can be important differences between the submitted version and the official published version of record.

People interested in the research are advised to contact the author for the final version of the publication, or visit the DOI to the publisher's website.

- The final author version and the galley proof are versions of the publication after peer review.

- The final published version features the final layout of the paper including the volume, issue and page numbers.

Link to publication

\footnotetext{
General rights rights.

- You may freely distribute the URL identifying the publication in the public portal. please follow below link for the End User Agreement:

www.umlib.nl/taverne-license

Take down policy

If you believe that this document breaches copyright please contact us at:

repository@maastrichtuniversity.nl

providing details and we will investigate your claim.
}

Copyright and moral rights for the publications made accessible in the public portal are retained by the authors and/or other copyright owners and it is a condition of accessing publications that users recognise and abide by the legal requirements associated with these

- Users may download and print one copy of any publication from the public portal for the purpose of private study or research.

- You may not further distribute the material or use it for any profit-making activity or commercial gain

If the publication is distributed under the terms of Article $25 \mathrm{fa}$ of the Dutch Copyright Act, indicated by the "Taverne" license above, 


\section{Relatief onaantastbaar}

\section{Inleiding}

Mijnheer de rector, geachte aanwezigen,

Het openbaar bestuur doet in dit land veel, maar juridisch gezien is zijn kernactiviteit het nemen van besluiten. "Besluit" heeft in het bestuursrecht een beperktere betekenis dan in het spraakgebruik. In het spraakgebruik kunnen wij zeggen dat de Minister van Justitie "besluit" om een werkbezoek te brengen, een persconferentie te geven of een pand te huren. Voor bestuursjuristen zijn dat geen besluiten. Wij verstaan onder besluiten slechts de publiekrechtelijke rechtshandelingen van bestuursorganen. Het zijn beslissingen, waarbij een bestuursorgaan éénzijdig rechten of plichten van burgers vaststelt. Deze week ontving ik een een schoolvoorbeeld van zo'n besluit, in een blauwe envelop: een belastingaanslag. Andere schoolvoorbeelden zijn het besluit om iemand een WAO-uitkering, een bouwvergunning of een verblijfsvergunning toe te kennen of te weigeren.

Als zo'n besluit u onaangenaam treft, hoeft u zich daar niet zonder meer bij neer te leggen. Meestal kunt u tegen zo'n besluit bezwaar maken bij het bestuursorgaan dat het besluit heeft genomen en bijna altijd kunt u tegen het besluit uiteindelijk in beroep gaan bij de rechter. Maar dan geldt een hele harde regel: dat moet u binnen zes weken doen. Anders wordt het besluit onherroepelijk. Het krijgt formele rechtskracht. Het wordt in rechte onaantastbaar. Allemaal juristenjargon voor: dan kunt u er niets meer aan doen. Al toont u duizend keer aan dat het een fout besluit is: dat is dan jammer, maar helaas. Had u maar eerder moeten piepen.

Over deze onaantasbaarheidsregel gaat deze rede. Ik zal betogen, dat deze regel weliswaar noodzakelijk is, maar in Nederland soms te streng of te rigide wordt ingevuld en toegepast. Daarbij zal ik mij onder meer beroepen op de rechtspraak van twee Europese gerechtshoven. Ik zal voorts betogen dat dit op het terrein van de overheidsaansprakelijkheid tot maatschappelijk ongewenste uitkomsten leidt. Voor de insiders: het gaat zowel over kippepoten als over pannekoeken. Voor de rest wordt deze kryptische zin straks wel duidelijk. Maar eerst moet ik iets meer zeggen over de onaantastbaarheidsregel zelf en daarvoor nog iets over terminologie.

\section{Terminologie}

Ik gebruikte zojuist drie aanduidingen voor de eigenschap van een besluit, dat het niet meer kan worden aangevochten. Soms noemen wij zo'n besluit onherroepelijk. Dat is verwarrend en soms zelfs onjuist, want een besluit dat niet meer door een burger kan worden aangevochten, kan soms nog wél door het bestuur worden herroepen.

"Formele rechtskracht" duidt van oorsprong op een specifieke vorm van onaantastbaarheid, namelijk onaantastbaarheid voor de burgerlijke rechter. Daarom is het minder geschikt als algemene aanduiding, hoewel het eigenlijk wel precies aangeeft wat er aan de hand is: het besluit heeft rechtskracht, die het niet ontleent aan zijn inhoud, maar aan het enkele feit dat er geen bezwaar of beroep meer tegen openstaat. Daarom houd ik het op "in rechte onaantastbaar", zij het dat ik dit meestal bekort tot "onaantastbaar" zonder meer.

\section{De onaantastbaarheidsregel}

De onaantastbaarheidsregel houdt in, dat een besluit in beginsel onaantastbaar wordt als de beschikbare bestuursrechtelijke rechtsmiddelen niet, niet tijdig of tevergeefs zijn gebruikt. Een dergelijke regel komt in alle mij bekende Europese rechtsstelsels voor en ik vermoed, dat zij ook in de mij onbekende voorkomt. De onaantastbaarheidsregel dient immers een waarde 
die ieder rechtsstelsel noodzakelijkerwijs moet dienen: de rechtszekerheid. Recht moet mensen zekerheid bieden, opdat zij zich naar het recht kunnen gedragen. Zonder dat kan het recht ook geen rechtvaardigheid bieden. Zelfs waar rechtszekerheid en rechtvaardigheid botsen, moet rechtszekerheid soms voorrang krijgen.

De onaantastbaarheidsregel is daarvan een voorbeeld. Zij brengt mee, dat het recht onjuiste besluiten soms toch geldig acht. Of nauwkeuriger: dat het recht zich niet eens meer afvraagt of een besluit inhoudelijk juist is. Want daar gaat het om. De onaantastbaarheidsregel is het equivalent van het machtswoord van de redactie van een ingezonden-brieven-rubriek: discussie gesloten. Zolang een besluit kan worden aangevochten, is onzeker of het geldig is. Dat is tot op zekere hoogte onvermijdelijk, want in een rechtsstaat moeten burgers zich tegen onjuiste overheidsbesluiten kunnen verweren. Maar de periode van onzekerheid mag niet eindeloos duren.

Daarom binden alle mij bekende Europese rechtsstelsels de bevoegdheid om bestuursrechtelijke rechtsmiddelen in te stellen aan een relatief korte termijn. In wezen is dit slechts een bestuursrechtelijke verschijningsvorm van een algemener beginsel, dat wij ook in andere rechtsgebieden terugvinden. De bevoegdheid om rechten of rechtsregels in concreto tot gelding te brengen is bijna altijd in de tijd beperkt. Zo kennen het privaatrecht en het strafrecht de verjaring. Ook die brengen mee, dat soms iemand die materieel gelijk heeft, dat niet meer krijgt. Sterker nog, zowel de verjaring als de onaantastbaarheidsregel zijn vooral bedoeld voor mensen die gelijk hebben. Want mensen die geen gelijk hebben, konden het als het goed is toch al niet krijgen.

\section{De beroepstermijn}

Aldus de traditionele argumentatie voor de korte bezwaar- en beroepstermijn - kortheidshalve zeg ik hierna beroepstermijn - in het bestuursrecht. Die termijn is in Nederland meestal zes weken, in Duitsland meestal een maand, in Frankrijk en in het gemeenschapsecht meestal twee maanden en in Engeland varieert zij van zes weken tot drie maanden. Europees gezien lopen wij dus redelijk in de pas.

Maar in het privaat- en strafrecht worden de meeste verjaringstermijnen niet in weken of maanden, maar in jaren uitgedrukt. Als iemand u mishandelt, heeft $u$ in beginsel vijf jaar de tijd om de letselschade op hem te verhalen en mag het OM jarenlang nadenken of het de dader gaat vervolgen. Maar als u meent arbeidsongeschikt te zijn geworden, maar het UWV u niettemin een WAO-uitkering weigert, moet $\mathrm{u}$ binnen zes weken beslissen of $\mathrm{u}$ de juridische strijd aangaat. Dat is verhoudingsgewijs erg kort en in de praktijk soms te kort, bijvoorbeeld omdat u juridisch advies moet inwinnen. Dat is weliswaar niet verplicht, maar meestal wel verstandig.

Bovendien handhaaft de rechter deze termijn onverbiddelijk. Een termijnoverschrijding kan verontschuldigd worden, maar dan moet u een heel sterk verhaal hebben. Met middelbare-school-smoezen als 'ik had het druk', 'ik was op vakantie', of 'de brief was zoek' hoeft u echt niet aan te komen. Voorts is de termijn van openbare orde. Soms wil een bestuursorgaan van een termijnoverschrijding geen punt maken, omdat het liever inhoudelijk met $\mathrm{u}$ in discussie gaat. Maar dat mag het bestuur niet. De rechter vindt, dat het bestuur van een termijnoverschrijding een punt moet maken.

Waarom moet dat zo kort en zo streng? Het traditionele argument is weer de rechtszekerheid. Maar die argumentatie is onvolledig. Rechtszekerheid is geen kwestie van alles of niets. Er zijn gradaties van rechtszekerheid. Een termijn van zes maanden die wat soepeler wordt toegepast zou ook rechtszekerheid brengen, hooguit iets minder. Maar mischien is iets minder soms wel genoeg.

Het argument van de rechtszekerheid gaat namelijk wel op, maar het gaat niet voor het gehele bestuursrecht en voor alle gevallen in dezelfde mate op. De rechtszekerheid weegt niet 
in alle situaties even zwaar. Aan de andere kant van de weegschaal kunnen de gevolgen van een onjuist besluit dat wegens termijnoverschrijding niet wordt gecorrigeerd soms heel groot zijn. Toch hebben wij voor alle besluiten dezelfde beroepstermijn en dezelfde strenge regels voor termijnoverschrijdingen. Ik vraag mij af, of de harmonisatie hier niet te ver is doorgeschoten. Volgens mij zijn wij in een deel van het bestuursrecht onnodig streng voor de burger, ten koste van diens rechtsbescherming. Anders gezegd: is in een deel van het bestuursrecht de balans tussen rechtszekerheid en individuele rechtvaardigheid teveel naar de rechtszekerheid doorgeslagen. Volgens mij is een meer gedifferentieerd stelsel mogelijk, dat meer recht doet aan de wenzenlijke verschillen binnen het bestuursrecht.

Wellicht verbaast het sommigen om dit uit mijn mond te horen. De uniforme beroepstermijn geldt immers sinds 1994 als een schoolvoorbeeld van de harmoniserende werking van de Algemene wet bestuursrecht. En velen van u kennen mij als fervent voorstander en zelfs letterlijk beroepsvoorstander van de Awb. Weest u gerust - of zo u wilt teleurgesteld - ik ben niet van mijn geloof gevallen. Ik ben inderdaad een groot voorstander van de Awb en dat blijf ik ook.

Ik bepleit ook geen terugkeer naar de donkere tijden voor de Awb. Het kwaad dat de Awb wil bestrijden, is departementaal en rechterlijk particularisme. Harmonisatie keert zich tegen onnodige verschillen. Tegen verschillen die voortkomen uit de mentaliteit van: wij doen het zo omdat wij het zo doen. Harmonisatie keert zich niet tegen verschillen waarvoor een goede inhoudelijke reden bestaat. Differentiatie is iets anders dan chaos. Ik bepleit ook niet om het weer aan de bijzondere wetgever over te laten. Ik bepleit een inhoudelijke verfijning binnen de Awb.

Laat ik ter illustratie eerst een voorbeeld noemen waarin het geldende recht naar mijn mening wel voldoet. Dat is de voor bestuursjuristen klassieke ballade van de bouwer en de buurman. Iemand krijgt een vergunning om zijn huis te verbouwen, maar weet dat zijn buurman daartegen is en juridische stappen overweegt. Dan heeft de bouwer er veel belang mee om zo snel mogelijk te weten of zijn vergunning inderdaad wordt aangevochten. Weliswaar mag hij strikt genomen al gaan bouwen, maar als hij dat doet en de rechter anderhalf jaar later zijn vergunning vernietigt, moet hij de schade van zijn buurman vergoeden. Soortgelijke argumenten gelden bij andere besluiten, waarbij verschillende belanghebbenden tegengestelde belangen hebben. Dan rechtvaardigt de rechtszekerheid van de ene burger - de bouwer - een beperking van de rechtsbescherming van de andere burger de buurman.

Maar neem nu een financieel besluit waarbij geen derden betrokken zijn, bijvoorbeeld over huursubsidie of kinderbijslag. Of mijn deze week ontvangen voorlopige aanslag inkomstenbelasting 2005. Daarvoor gelden dezelfde korte beroepstermijn en dezelfde strenge regels over termijnoverschrijding. Maar wiens rechtszekerheid beschermen wij dan eigenlijk? Niet die van de aanvrager of belastingplichtige. Als je die na zes weken niet-ontvankelijk verklaart, biedt je hem slechts een zekerheid die hij niet wil, namelijk de zekerheid dat hij met lege handen staat. Ook niet de rechtszekerheid van derden-belanghebbenden, want die zijn er niet. Het gaat slechts om de rechtszekerheid van het bestuur.

$\mathrm{Nu}$ heeft de Centrale Raad van Beroep er al lang geleden op gewezen, dat ook het bestuur aanspraak heeft op rechtszekerheid. Akkoord. Maar is die behoefte bij financiële besluiten zo groot, dat zij een beroepstermijn van zes weken rechtvaardigt? Ik begrijp best, dat de overheid zo snel mogelijk zekerheid wil over de omvang van haar financiële verplichtingen en aanspraken. Maar dat willen bedrijven en particulieren ook en die krijgen die zekerheid niet binnen zes weken. Ik begrijp ook best, dat het bestuur een dossier een keer wil kunnen sluiten. Maar dan wil het vooral zekerheid over het tijdstip waarop dat kan. De afstand tussen dat tijdstip en het besluit is minder belangrijk. Volgens mij zouden de Belastingdienst, de SVB of het UWV zonder problemen kunnen werken met een 
beroepstermijn van zes maanden in plaats van zes weken. Je moet er alleen even de organisatie op instellen.

Eigenlijk zou ik de huidige termijn van zes weken dan ook willen beperken tot de gevallen waarin zij echt nodig is. Maar dan wordt de wetgevingsjurist in mij wakker en vraagt: "Hoe schrijf je dat op?" Dat blijkt niet zo eenvoudig - geloof mij: ik heb het geprobeerd - omdat het niet alleen gaat om besluiten waarbij derden met tegengestelde belangen betrokken zijn, maar bijvoorbeeld ook om gevallen waarin het beroep schorsende werking heeft. Maar een langere beroepstermijn voor financiële besluiten kan wel. Die categorie wordt al in de wet omschreven, namelijk in artikel 4:12 Awb.

Derhalve bepleit ik voor zuiver financiële besluiten een beroepstermijn van bijvoorbeeld zes maanden. Ik besef, dat dat ook arbitrair is. Ik besef eveneens, dat je ook dan vroeg of laat een beroepschrift krijgt dat één dag te laat is. Maar je krijgt die wel veel minder. Bij financiële besluiten is het immers meestal ook in het belang van appellant om snel in beroep te komen. Maar ik vind het niet redelijk, om hem dat al na zes weken in te peperen door hem niet-ontvankelijk te verklaren. Die sanctie is soms gewoon onevenredig zwaar in verhouding tot zijn verzuim.

Om dezelfde reden pleit ik voor nuancering van de regel, dat de beroepstermijn van openbare orde is. Dat het bestuur niet zomaar coulant kan zijn jegens de buurman, omdat het daarmee de bouwer benadeelt, begrijp ik. Maar in de sociale zekerheid, het belastingrecht of het subsidierecht speelt dit helemaal niet. Op die terreinen beschermt de onaantastbaarheidregel slechts de belangen van het bestuur. Als het bestuur daar niet moeilijk over wil doen, waarom zou de rechter dan zeggen dat dat wel moet?

\section{Terugkomen op}

Op dit laatste punt past een nuancering. Soms mag het bestuur via een omweg wel coulant zijn. U kunt het bestuursorgaan vragen om op een onaantastbaar besluit terug te komen. Maar dan bent u een smekeling met een uitgesproken zwakke positie. Het bestuur behoeft zo'n verzoek slechts inhoudelijk te behandelen als u kunt wijzen op nieuwe feiten die een ander licht op de zaak kunnen werpen en die u redelijkerwijs niet eerder had kunnen aanvoeren. Als u dat niet kunt, dan mag het bestuur uw verzoek per kerende post afwijzen met een beroep op de onaantastbaarheid van het eerdere besluit.

Maar in die situatie mág het bestuur ook coulant zijn. Het mág uw verzoek wel opnieuw inhoudelijk behandelen. Indien de belangen van derden zich daartegen niet verzetten, mag het zelfs daadwerkelijk op het onaantastbare besluit terugkomen. Zo mag de minister van $\mathrm{V}$ en I de dossiers van uitgeprocedeerde asielzoekers opnieuw beoordelen. Als u na afloop van de bezwaartermijn een rekenfout in uw belastingaanslag ontdekt, dan mag de inspecteur die aanslag ambtshalve verminderen.

Dat mag, maar moet niet. Als de minister of inspecteur uw verzoek afwijst, staat u zeer zwak. In het belastingrecht kunt u tegen zo'n afwijzing überhaupt niet in beroep. In het overige bestuursrecht wel, maar dan beoordeelt de rechter slechts, of er wel of niet sprake was van nieuwe feiten of omstandigheden. Zo niet, dan kijkt de rechter niet meer naar de inhoud van de zaak.

De Afdeling bestuursrechtspraak wijst er in dit verband op, dat, vrij vertaald, van de beroepstermijn en de onaantastbaarheidregel weinig zou overblijven, als iemand een onaantastbaar besluit via de omweg van een verzoek om daarop terug te komen gewoon alsnog of zelfs ten tweede male aan de rechter zou kunnen voorleggen. In beginsel is dat natuurlijk juist. Daarom mag het bestuur bij het ontbreken van nieuwe feiten in beginsel weigeren op een onaantastbaar besluit terug te komen. Maar, anders dan de Afdeling lijkt te suggereren, betekent dit niet dat zo'n weigering nooit door de rechter kan worden getoetst. Want als dat zo zou zijn, zou het bestuur beschikken over een bevoegdheid die niet door het 
recht wordt begrensd en dat is een rechtsstaat onbestaanbaar. Bestuursbevoegdheden kunnen ruim zijn, zoals in dit geval, maar in een rechtsstaat zijn zij nooit, maar dan ook nooit, onbegrensd. Dat is de absolute bottom line van het bestuursrecht. De Centrale Raad van Beroep erkent dat gelukkig ook nog altijd met zoveel woorden.

Zo mag het bestuur zich ook bij een beslissing om al dan niet op een onaantastbaar besluit terug te komen, niet schuldig maken aan willekeur. Het bestuur mag het beleid hebben om in beginsel niet terug te komen of het beleid om dat in beginsel wel te doen als het besluit een fout bevat, maar het mag niet het beleid hebben om het alleen te doen als de zon schijnt en niet als het regent. Het mag het ook niet van de luimen van de behandelend ambtenaar laten afhangen. Het mag ook niet in strijd met het gelijkheidsbeginsel handelen. Als de ene uitgeprocedeerde asielzoeker alsnog mag blijven omdat hij een ernstige ziekte heeft die in zijn land van herkomst niet kan worden behandeld, dat mag een ander met dezelfde ziekte uit hetzelfde land ook blijven.

Kortom, de onaantastbaarheidregel is wel hard, maar niet absoluut. De rechtszekerheid moet worden gediend, maar niet tot elke prijs. Ook een weigering om terug te komen op een onaantastbaar besluit moet voldoen aan de norm van artikel 3:4, tweede lid, Awb, dat de gevolgen van een besluit niet onevenredig mogen zijn in verhouding tot de met het besluit te dienen doelen. Er zijn gevallen denkbaar waarin het vasthouden aan de onaantastbaarheid van een besluit zo onredelijk uitpakt, dat het rechtens ontoelaatbaar wordt. Ik vind hiervoor steun in het arrest-Heesch/van de Akker van de Hoge Raad, waarin de Hoge Raad de onaantastbaarheidregel vooropstelt, maar er meteen bij zegt dat de aan die regel verbonden bezwaren onder omstandigheden zo klemmend kunnen worden, dat een uitzondering moet worden aanvaard. Wij weten inmiddels dat dat hoge uitzonderingen zijn, maar ze zijn er wel. Heecsh/Van de Akker zelf, bijvoorbeeld, betrof een geval waarin de overheid de burger min of meer had misleid over zijn beroepsmogelijkheden.

Het arrest-Dangeville van het Europese Hof voor de Rechten van de Mens wijst in dezelfde richting. Het betrof een geval waarin de Franse belastingdienst en de Franse rechter star vasthielden aan de formele onaantastbaarheid van een besluit waarvan de belastingdienst zelf erkende dat het evident onjuist was, met aanzienlijk financiële gevolgen voor Dangeville. Dit leverde volgens het Hof een schending van Dangeville's eigendomsrecht onder artikel 1 Eerste Protocol bij het EVRM op. Ook het Straatsburgse Hof vindt dus in ieder geval, dat op een onaantastbaarheidregel uitzonderingen mogelijk moeten zijn. Meer kunnen wij er niet uit afleiden, want het arrest is zeer zwak gemotiveerd. Dat neemt echter niet weg, dat uit het voorgaande naar mijn oordeel volgt dat de rechter een weigering om terug te komen op een onaantastbaar besluit wel degelijk inhoudelijk moet toetsen, al is het maar zeer marginaal.

\section{Het gemeenschapsrecht}

Toetsen moet de rechter trouwens toch, want wij weten inmiddels dat onder omstandigheden ook het gemeenschapsrecht kan verplichten tot het terugkomen op een in rechte onaantastbaar besluit. Daarmee zijn wij bij de kippenpoten. Want er was eens een bedrijf, Kuhne \& Heitz, dat onder meer kippenvlees exporteerde naar buiten de EU. Het ontving daarvoor exportrestituties, een soort subsidies. Nu zijn die restituties voor kippendijen hoger dan voor ander pluimveevlees. Kuhne had aangifte gedaan van export van kippendijen en daarvoor ook restituties gekregen. Maar bij een controle constateerde het productschap dat aan die dijen ook nog een stuk kippenrug vastzat. Dat komt door de wijze waarop die arme beesten machinaal worden geslacht, maar ik zal u de details besparen. Het productschap vond dat daardoor geen sprake meer was van kippendijen in de zin van de desbetreffende Europese verordening en vorderde een miljoen gulden aan restituties terug. Kuhne ging in beroep maar werd door het College van Beroep voor het bedrijfsleven in het ongelijk gesteld. Het $\mathrm{CBb}$ vond het daarbij 
niet nodig om prejudiciële vragen aan het Hof van Justitie te stellen. Daarmee was het terugvorderingsbesluit onaantastbaar.

Enige tijd later stelt het gerechtshof Den Haag in een zaak tegen een andere exporteur wel prejudiciële vragen over de uitleg van de desbetreffende bepaling van de verordening. Uit het antwoord van het Hof van Justitie in dit arrest-Voogd, blijkt dat het CBb in de zaak-Kuhne die bepaling verkeerd had uitgelegd. Het inmiddels onaantastbare terugvorderingsbesluit blijkt achteraf wel degelijk in strijd met het gemeenschapsrecht. Kuhne verzoekt het productschap daarom op dit besluit terug te komen, maar het productschap weigert dit. Kuhne gaat opnieuw in beroep. Ditmaal stelt het $\mathrm{CBb}$ wel een prejudiciële vraag, namelijk of uit het gemeenschapsrecht een verplichting voortvloeit om op het besluit terug te komen. Het wijst daarbij in het bijzonder op artikel 10 EG-verdrag, dat, kort gezegd, de lidstaten verplicht tot loyale medewerking bij de tenuitvoerlegging van het gemeenschapsrecht.

In zijn antwoord stelt het Hof van Justitie voorop, dat de rechtszekerheid ook in het gemeenschapsrecht als algemeen rechtsbeginsel is erkend. Naar Widdershoven terecht heeft benadrukt, is de onaantastbaarheidregel als zodanig dus niet in strijd met het gemeenschapsrecht. Maar het Hof formuleert wel een uitzondering op die regel: een bestuursorgaan moet een onaantastbaar, maar met het gemeenschapsrecht strijdig besluit opnieuw onderzoeken, indien aan vier voorwaarden is voldaan:

- $\quad$ het bestuursorgaan is naar nationaal recht bevoegd om op het besluit terug te komen;

- het besluit is onaantastbaar geworden door een uitspraak van de hoogste nationale rechter

- $\quad$ uit latere rechtspraak van het Hof blijkt dat deze uitspraak berust op een onjuiste uitleg van het gemeenschapsrecht, gegeven zonder prejudiciële vragen te stellen, en

- de belanghebbende heeft zich onmiddellijk na het bekende worden van de rechtspraak van het Hof tot het bestuursorgaan gewend.

In het geval Kuhne is aan deze voorwaarden voldaan. Naar alle waarschijnlijkheid krijgt Kuhne nu - na zowat vijftien jaar - eindelijk haar geld terug.

In mijn noot bij dit arrest merkte ik al op, dat het eigenlijk maar een klein deukje in de onaantastbaarheidregel slaat. Alleen als betrokkene alle nationale rechtsmiddelen tevergeefs heeft benut en de hoogste rechter heeft verzuimd prejudiciële vragen te stellen, kan de onaantastbaarheid van het besluit worden doorbroken. Maar het geeft wederom aan dat de onaantastbaarheidregel niet absoluut is, omdat rechtszekerheid wel belangrijk is, maar niet de enige waarde in ons recht.

Het betekent natuurlijk ook, dat de Nederlandse bestuursrechter in voorkomende gevallen zal moeten toetsen of aan de Kuhne-voorwaarden is voldaan.

Want daar zullen geschillen over komen. Kuhne was is in wezen nog een eenvoudig geval: het Hof van Justitie beantwoordde in het arrest-Voogd exact dezelfde rechtsvraag die het $\mathrm{CBb}$ in de eerste uitspraak in de zaak-Kuhne moest beantwoorden. Het stond dus buiten twijfel dat de CBb-uitspraak onjuist was. Maar we gaan natuurlijk zien, dat een belanghebbende met een beroep op een arrest van het Hof vraagt terug te komen op een onaantastbaar besluit, maar het bestuur dit weigert met het argument dat het geval van verzoeker net een slagje anders ligt dan dat waarop het arrest ziet.

Bovendien is het de vraag of het bij Kuhne blijft. Er liggen bij het Hof inmiddels twee vervolgzaken. De ene, de zaak-Kapferer, betreft de vraag of onder de in Kuhne gestelde voorwaarden ook een onherroepelijke rechterlijke beslissing moet worden herzie; dat thema laat ik vandaag rusten. Voor ons interessanter zijn de gevoegde zaken ISIS en i-21. Dat zijn twee Duitse telecombedrijven, van wie door de Duitse telecomautoriteit elk zo'n 5,5 miljoen euro aan leges is geheven voor een vergunning. Zij gaan daartegen niet in beroep. Vervolgens beslist het Bundesverwaltungsgericht op het beroep van een derde onderneming dat de leges in strijd met de terzake toepasselijke richtlijn machtigingen en vergunningen zijn geheven. 
Dan vorderen ook ISIS en i-21 hun geld terug. Bij het bestuur en bij de lagere rechter vangen zij bot, hoewel vaststaat dat het bestuur naar Duits recht wel bevoegd is om op het legesbesluit terug te komen. Het Bundesverwaltungsgericht vraagt vervolgens aan het Hof van Justitie of artikel 10 EG in samenhang met de desbetreffende richtlijn zo moet worden uitgelegd, dat ook de niet aangevochten legesbesluiten moeten worden ingetrokken.

Het cruciale verschil met de zaak-Kuhne is, dat de twee telecombedrijven hun nationale rechtsmiddelen niet hebben uitgeput. In de Nederlandse literatuur en rechtspraak is tot dusver algemeen aangenomen, dat in dat geval de onaantastbaarheidregel niet in strijd is met het gemeenschapsrecht. Ook ik denk nog steeds dat dit in zijn algemeenheid juist is. In zijn algemeenheid mag van burgers en bedrijven worden gevergd, dat zij beschikbare nationale rechtsmiddelen benutten. Uit de verwijzingsuitspraak in de zaken ISIS en i-21 blijkt ook niet van enige reden waarom dat in concreto niet zou kunnen worden gevergd. Maar het Bundesverwaltungsgericht is er kennelijk niet gerust op.

Er zijn echter wel situaties, waarin je je kunt afvragen of redelijkerwijs nog van belanghebbenden kunt vergen dat zij beroep instellen. Dit doet zich voor bij wat ik noem repeterende besluiten. Nadat Kuhne haar zaak aanvankelijk bij het CBb had verloren, heeft het bedrijf nog vele malen partijen kippenvlees geëxporteerd. Iedere keer kwam er dan een besluit over de exportrestituties, dat telkens berustte op dezelfde, later onjuist gebleken rechtsopvatting. Kuhne heeft daartegen natuurlijk niet telkens opnieuw beroep ingesteld, want zij kon uit de uitspraak van het CBb geen andere conclusie trekken dan dat zo'n beroep kansloos zou zijn geweest. Kuhne had het productschap tevergeefs gevraagd om ook op die besluiten terug te komen. Het $\mathrm{CBb}$ achtte die weigering terecht en vond het ook niet nodig daarover prejudiciële vragen te stellen. Naar mijn oordeel zou hier echter plaats zijn voor een nadere uitzondering op de onaantastbaarheidregel. Van een belanghebbende mag worden verwacht dat hij tegen een volgens hem onjuiste rechtsopvatting van het bestuur in rechte opkomt, maar niet dat hij, nadat hij dat tot in hoogste instantie tevergeefs heeft gedaan, eindeloos met zijn hoofd tegen dezelfde muur blijft bonken. Daarin verschilt de positie van Kuhne wezenlijk van die van een bedrijf, dat nooit tegen de later onjuist gebleken rechtsopvatting heeft geageerd. In de schriftelijke versie van deze rede werk ik dat iets verder uit. Hier zie ik het vooral als een voorbeeld van de meer algemene gedachte die als een rode draad door deze rede loopt, namelijk dat wij de onaantastbaarheidregel ook in die zin moeten relativeren, dat wij ons moeten afvragen of de gevolgen van de onaantastbaarheidregel ook in concreto nog aanvaardbaar zijn en door de rechtszekerheid kunnen worden gerechtvaardigd.

\section{Overheidsaansprakelijkheid}

Tot slot een opmerking over de betekenis van de onaantastbaarheidregel voor de overheidsaansprakelijkheid, de formele rechtkracht in strikte zin. Dat leerstuk is door de burgerlijke rechter ontwikkeld ten behoeve van de taakverdeling met de bestuursrechter. In Nederland legt de burgerlijke rechter zijn bevoegdheid zo ruim uit, dat hij eigenlijk altijd bevoegd is. Daarnaast heeft de wetgever bestuursrechters belast met het kennisnemen van geschillen over besluiten. De bevoegdheden van beide rechters overlappen dus. De wetgever heeft dit nooit opgelost, dus heeft de burgerlijke rechter dat zelf maar gedaan. Zijn oplossing komt er op neer, dat hij zich onthoudt van een eigen oordeel over de rechtmatigheid van besluiten. Dat heeft onder meer tot gevolg, dat je bij de burgerlijke rechter geen vergoeding kunt vorderen van schade, veroorzaakt door een onaantastbaar besluit. Dat is, alweer, een goed uitgangspunt. Maar, alweer, het behoeft soms relativering. Ik stip een enkel punt aan.

Het eerste punt brengt ons bij het toetje, de pannenkoeken. Pannenkoekhuis De Kabouter was een bloeiende onderneming, totdat de provincie besloot de weg waaraan het was gelegen ingrijpend te reconstrueren, waardoor het pannenkoekhuis minder bereikbaar werd en fors omzetverlies leed. Toch vocht onze kabouter het besluit tot reconstructie van de 
weg niet aan. Het bedrijf had namelijk niets tegen deze reconstructie. Die was in ons aller belang. In het algemeen belang. Maar de lasten die zo'n project onvermijdelijk ook meebrengt, drukten eenzijdig op dat ene bedrijf dat toevallig aan die weg was gelegen. Dat is niet eerlijk. Ons recht kent dan ook een beginsel van de gelijkheid voor de publieke lasten. Dat beginsel verbiedt, dat enkelen de lasten moeten dragen van een overheidsbesluit waarvan allen de lusten zullen hebben. In zo'n geval moeten de enkelen worden gecompenseerd. Wij noemen dit nadeelcompensatie. In zo'n geval hebben de enkelen dus recht op schadevergoeding, niet omdat de overheid onrechtmatig heeft gehandeld, maar omdat de lasten van rechtmatig overheidshandelen oneerlijk zijn verdeeld.

Helaas heeft de Hoge Raad nog altijd niet erkend, dat ook rechtmatig handelen tot schadevergoeding kan verplichten. Hij erkent wel het beginsel van de gelijkheid voor de publieke lasten, maar plaatst schending daarvan nog altijd in de sleutel van de onrechtmatige daad. Hij grijpt daarbij aan bij artikel 3:4, tweede lid, Awb. Daar staat dat de gevolgen van een besluit niet onevenredig mogen zijn aan de daarmee gediende doelen. De toelichting leest daarin een grondslag voor nadeelcompensatie, maar de bestuursrechtelijke consensus is inmiddels, dat artikel 3:4 dat niet is, omdat het ziet op een ander soort evenredigheid.

Het gevolg hiervan werd duidelijk, toen ons pannenkoekhuis bij de burgerlijke rechter vergoeding vorderde van de schade die het door de wegreconstructie leed. De Hoge Raad wees deze vordering af, omdat het besluit tot wegreconstructie onaantastbaar was. Volgens de Hoge Raad moest het bestuur reeds bij het nemen van het besluit afwegen of het Pannenkoekhuis recht had op nadeelcompensatie. Nu de bestuursrechter het besluit niet heeft vernietigd, moet de burgerlijke rechter er volgens de Hoge Raad van uit gaan dat het bestuur dat correct heeft gedaan.

Diverse schrijvers - ik noem de collega's Schueler, Schlössels en Van Maanen hebben er op gewezen dat dit een ongelukkige uitspraak is. Dat is het niet alleen omdat de provincie de facto niet had nagedacht over nadeelcompensatie voor het pannenkoekhuis, maar ook om twee andere redenen. In de eerste plaats lokt zij onnodige beroepen uit, die voor onnodige vertraging van infrastructurele projecten zorgen. Ook iemand die niets tegen het project heeft, maar slechts zijn schade vergoed wil zien, moet in de leer van de Hoge Raad immers zekerheidshalve ook het besluit omtrent het project zelf aanvechten. Aan dat soort beroepen heeft niemand behoefte, ook die burger zelf niet. Hier leidt strikte toepassing van de onaantastbaarheidregel dus tot een maatschappelijk ongewenst resultaat. Onder meer Roozendaal heeft er op gewezen, dat een beter resultaat kan worden bereikt door toepassing van het eigen-schuld-criterium en de schadebeperkingsplicht. Dat biedt ruimte om af te wegen of van de burger redelijkerwijs kon worden verwacht dat hij beroep instelde.

In de tweede plaats is het niet wenselijk, het bestuur te verplichten om reeds bij de principe-beslissing omtrent het project een oordeel te geven over alle mogelijke nadeelcompensatieclaims. Dat is gewoon te ingewikkeld.

De eerlijkheid gebiedt te zeggen, dat de kern van dit probleem ergens anders ligt, namelijk in de weigering van de Hoge Raad om te erkennen dat ook rechtmatige handelingen onder omstandigheden tot schadevergoeding kunnen verplichten. De Hoge Raad erkent het beginsel van de gelijkheid voor de publieke lasten inmiddels als rechtsbeginsel, maar ziet het niet als zelfstandige bron van verbintenissen. Hij wringt nadeelcompensatieclaims nog altijd in de sleutel van de onrechtmatige daad.

Dat is jammer, maar zolang dat zo is, is het pannekoekenhuisprobleem een voorbeeld van een meer algemeen probleem. Als gezegd is de leer van de formele rechtskracht ooit ontwikkeld ten behoeve van de bevoegdheidsafbakening tussen burgerlijke rechter en bestuursrechter. Dat verklaart de rigide toepassing: bevoegdheidscriteria moeten bij voorkeur "hard and fast rules" zijn. Maar zoals met name Van Maanen - die zich, sinds de bestuursjuristen zich aan het aansprakelijkheidsrecht zijn gaan vergrijpen, aan de 
civielrechtelijke zending onder de bestuursrechtelijke heidenen heeft gewijd - heeft uiteengezet, heeft het bevoegdheidscriterium in de loop der jaren ook materiële gevolgen gekregen, die soms ongelukkig zijn.

Het meer algemene probleem is, dat de Hoge Raad het oordeel van de bestuursrechter over de rechtmatigheid van een besluit blind overneemt. Dat is ongelukkig, omdat bestuursrechter en burgerlijke rechter voor verschillende vragen staan. Voor de bestuursrechter is de primaire vraag of het besluit geldig is. Voor de burgerlijke rechter is de primaire vraag of het bestuur jegens eiser zodanig onrechtmatig heeft gehandeld, dat eiser aanspraak heeft op schadevergoeding. Dat zijn twee verschillende vragen.

Soms is een besluit geldig, maar heeft het bestuur door de hele gang van zaken daaromheen jegens de belanghebbende toch onrechtmatig gehandeld. Omgekeerd betekent niet iedere vernietiging door de bestuursrechter, dat het bestuur jegens belanghebbende onrechtmatig heeft gehandeld. Er is een verschil tussen de geldigheid van een besluit en de al dan niet rechtmatigheid daarvan jegens individuele burgers.

Dat is geen nieuw inzicht. Het wordt al jaren betoogd door Tak, die er echter conclusies aan verbindt die ik vaak niet kan delen. Het is recent ook betoogd door onder meer Van Maanen, Schlössels en Schueler en de door de Commissie Rechtsbescherming van de VAR, waarvan ik, voor de goede orde, overigens lid was. Het enige wat ik daaraan kan toevoegen, is dat het probleem door recente ontwikkelingen in het bestuursrecht eerder groter dan kleiner wordt.

De trend in het bestuursrecht is, om vernietigingen om formele redenen waar mogelijk te vermijden. Ik juich dat toe, maar het betekent ook, dat de kans groter wordt dat iemand schade lijdt door fouten bij de voorbereiding van een besluit dat uiteindelijk materieel juist blijkt. Denk aan degene die volstrekt onjuist is voorgelicht.

Omgekeerd hebben wij het debat over de argumentatieve fuik. Het schoolvoorbeeld is dat van de tandarts die een toevoeging op grond van de Wet op de rechtsbijstand wilde. Die werd hem geweigerd omdat hij een vermogen had. Hij beweerde, dat dit vermogen negatief was, omdat hij een onderhandse lening was aangegaan. Hoewel hij daar herhaaldelijk om was gevraagd, kwam hij pas in hoger beroep met het bewijs van die lening. De Afdeling verwierp daarom zijn beroep. Daar is veel kritiek op gekomen. Maar zelfs degenen die vinden dat de Afdeling had moeten vernietigen omdat het besluit onjuist was, zullen toch met mij eens zijn dat het te grijs zou zijn als die nalatige tandarts ook nog schadevergoeding zou krijgen. Dat toont aan, dat niet iedere vernietiging betekent dat het besluit onrechtmatig was.

Wij moeten dus onderscheid maken tussen de geldigheid en de rechtmatigheid van een besluit. Schueler stelt, dat het huidige systeem van competentieverdeling daardoor op termijn tot de ondergang gedoemd is. Ik help het hem hopen. Maar tot die tijd betekent het in ieder geval, dat de onaantastbaarheidregel genuanceerder moet worden toegepast. Dat was mijn boodschap in deze rede. 
Dames en heren

Tot slot een woord van dank. Ik besef diep, dat ik hier sta dankzij velen. Ik betreur, dat ik nu geen tijd heb om hen allen te bedanken. Ik moet volstaan met enkelen.

Mijnheer de rector, leden van het College van Bestuur en van het College van Decanen en allen die aan mijn benoeming hebben medegewerkt: ik dank u voor het in mij gestelde vertrouwen. Dat is voor mij geen routine-formule. Ik ben niet gepromoveerd. U was bereid, daar overheen te stappen. In ruil daarvoor ga ik bewijzen, dat u daarin gelijk had.

Ik dank het Ministerie van Justitie voor het mogelijk maken van mijn leerstoel. Maar dat wil ik graag ook iets persoonlijker doen.

Hooggeachte Roes, beste Gerard. In Amerika worden leerstoelen vaak vernoemd naar degenen, die zich voor de totstandkoming daarvan hebben ingespannen. Als wij die gewoonte in Nederland zouden hebben, zou ik vandaag de Gerard Roes- leerstoel hebben aanvaard. Deze leerstoel bestaat dankzij jouw initiatief en jouw inspanning. Het is één van de uitingen van jouw visie, dat wetgeving en wetenschap elkaar wederzijds kunnen en moeten bevruchten. Daarvoor ben ik je zowel persoonlijk als professioneel zeer dankbaar.

Hooggeleerde Verhey, beste Luc. Jij hebt je hier in Maastricht zeer ingespannen voor deze leerstoel en voor mijn benoeming. En dat terwijl je wist, dat wij dan wéér elkaars brieven, elkaars telefoontjes en elkaars e-mails zouden krijgen. Ik ben je daarvoor zeer dankbaar. Op Justitie hebben wij samen mooie stukken gemaakt en dit jaar gaan wij dat voor de NJV weer doen. Ik hoop dat er nog meer zullen volgen.

Hooggeleerde Stroink, beste Frits. Er was eens een hoogleraar, toen nog aan de Open Universiteit, die een jong wetenschappelijk medewerker aan - toen nog - de Rijksuniversiteit Limburg vroeg of hij wilde meewerken aan een nieuwe losbladige over - toen nog - het voorontwerp Algemene wet bestuursrecht. Dat was in 1987. Jij schonk mij vertrouwen, toen ik nog niets had bewezen. Veel dank daarvoor. Bovendien: jij was degene, die mij op het spoor van de Awb zette. Ik geloof dat ik mag zeggen, dat dat niet zonder gevolgen is gebleven.

Jij hebt trouwens nog meer op je geweten. Jij hebt mij ooit voorgesteld aan een toenmalige promovendus van jou, die ik nu mag aanspreken als:

Hooggeleerde Widdershoven, beste Rob. Enkele minuten nadat Frits ons aan elkaar had voorgesteld, gingen wij samen ergens roken en over bestuursrecht praten. Zeventien jaar later doen wij dat nog steeds. Alleen praten we inmiddels over veel meer dan bestuursrecht. Ik hoop dat dat nog lang zo blijft. Ik heb ontzettend veel van jou geleerd en dank je daarvoor, maar vooral ook voor je vriendschap door de jaren heen.

Hooggeleerde Van der Meulen, beste Bernd. Onze wegen kruisen elkaar voortdurend, aan de VU, in Maastricht, in Utrecht. Op ons vakgebied lijk je wel alles te kunnen en zonodig vind je gewoon zelf een nieuw vakgebied uit. Dat is heel inspirerend. Dank je zeer.

Hooggeleerde Van Kreveld, beste Jan. Formeel mag ik je geloof ik niet meer zo noemen, maar die regel acht ik onverbindend wegens kennelijke onredelijkheid. Een hooggeleerde wordt niet opeens minder geleerd als hij voor een andere baan kiest. Jij hebt mij ooit naar Justitie gehaald. Daarvoor ben ik je eeuwig dankbaar, want jij hebt me het mooie vak van wetgevingsjurist geleerd, waaraan ik sedertdien ongeneeslijk verslingerd ben geraakt.

Beste mensen van de Disciplinegroep Staats- en bestuursrecht van de Universiteit Utrecht. Vier jaar lang vertoefde ik af en toe als een vreemde eend in jullie bijt. Ik dank jullie voor het feit dat die vreemdeling zich daar toch altijd thuis voelde.

Beste mensen van de Capaciteitsgroep Publiekrecht van de Universiteit Maastricht. In jullie midden ben ik niet zozeer een vreemdeling, maar meer een deelnemer aan een terugkeerprogramma. Het betekent heel veel voor mij, om weer te werken aan de faculteit die ooit mocht helpen opbouwen. Jullie steun heeft mij zeer geholpen bij het herinburgeren. Dank jullie zeer. 
Collega's van de Directie Wetgeving van Justitie: het is een voorrecht om met jullie te mogen werken. Er zijn maar weinig andere plaatsen, waar een jurist zijn vak op zo'n hoog niveau kan beoefenen. Dit geldt natuurlijk in het bijzonder voor de sector staats- en bestuursrecht, die natuurlijk de beste, maar vooral ook de gezelligste sector van de Directie is.

Meer in het bijzonder is daar het cluster bestuursrecht. Wat kan ik zeggen, mensen. Jullie zijn mijn eigen dream team. Het is mij een eer en genoegen, met jullie te mogen samenwerken.

Pa en Ma. Aan jullie heb ik alles te danken. De eigenschappen die essentieel zijn voor zowel een wetenschapper als een wetgevingsjurist: nieuwsgierigheid, eigenwijsheid, maatschappelijke betrokkenheid, de liefde voor de taal en zoveel meer, die heb ik allemaal van huis uit mee gekregen. Ooit dacht ik dat dat vanzelfsprekend was. Dat is niet zo, dus zeer bedankt voor alles.

Tot slot. Lieve Tamar. Jij weet niet half, hoeveel vreugde jij mij schenkt en hoeveel ik van jou heb geleerd. Het vaderschap is naast al het andere ook een leerzame ervaring. Je leert er bijvoorbeeld van, dat je strenge regels soms moet relativeren. Daarom ben ik je, juist omdat het in ons geval niet vanzelfsprekend was, dankbaar dat ik je vader mag zijn.

Ik heb gezegd. 